\title{
Harnessing rhizosphere microbiomes for drought-resilient crop production
}

DOI:

10.1126/science.aaz5192

\section{Document Version}

Accepted author manuscript

Link to publication record in Manchester Research Explorer

\section{Citation for published version (APA):}

Vries, F. T. D., Griffiths, R. I., Knight, C. G., Nicolitch, O., \& Williams, A. (2020). Harnessing rhizosphere microbiomes for drought-resilient crop production. Science, 368(6488), 270-274.

https://doi.org/10.1126/science.aaz5192

\section{Published in:}

Science

\section{Citing this paper}

Please note that where the full-text provided on Manchester Research Explorer is the Author Accepted Manuscript or Proof version this may differ from the final Published version. If citing, it is advised that you check and use the publisher's definitive version.

\section{General rights}

Copyright and moral rights for the publications made accessible in the Research Explorer are retained by the authors and/or other copyright owners and it is a condition of accessing publications that users recognise and abide by the legal requirements associated with these rights.

\section{Takedown policy}

If you believe that this document breaches copyright please refer to the University of Manchester's Takedown Procedures [http://man.ac.uk/04Y6Bo] or contact uml.scholarlycommunications@manchester.ac.uk providing relevant details, so we can investigate your claim.

\section{OPEN ACCESS}


Harnessing rhizosphere microbiomes for drought resilient crop production

3 Franciska T. de Vries ${ }^{1,2 *}$, Rob I. Griffiths ${ }^{3}$, Christopher G. Knight ${ }^{1}$, Oceane Nicolitch ${ }^{1}$, Alex Williams ${ }^{1}$

$4 \quad 1$ Department of Earth and Environmental Sciences, The University of Manchester, Oxford

5 Road, M13 9PT, Manchester, UK

$6 \quad 2$ Institute for Biodiversity and Ecosystem Dynamics, University of Amsterdam, PO

7 Box 94240, 1090 GE Amsterdam, The Netherlands.

$8 \quad{ }^{3}$ CEH Bangor, Environment Centre Wales, Deiniol Rd, Bangor, LL57 2UW

9 Twitter accounts - @SoilEcolUoM; @frantecol

*Corresponding author - f.t.devries@uva.nl

13 Key words: root exudates, root traits, microbiome, rhizosphere, plant-soil communication, 14 ecosystem function, climate change

Short title: Harnessing rhizosphere microbiomes

Single sentence summary: Mechanistic and field understanding of plant-microbiome interactions is crucial for securing food production under drought

Root-associated microbes can improve plant growth, and offer potential to increase crop resilience to future drought. While our understanding of the complex feedbacks between plant and microbial responses to drought is advancing, most of our knowledge comes from non-crop plants in controlled experiments. Here, we describe a framework for quantifying relationships between plant and microbial traits, and we propose that future research efforts should explicitly focus on food crops and include longer-term experiments under field conditions. Overall, we highlight that an improved mechanistic understanding of the complex feedbacks between plants and microbes during, and particularly after, drought through integrating ecology with plant, microbiome and molecular approaches - is central to making crop production more resilient to our future climate. 
Interactions between plants and soil organisms are crucial for the functioning of terrestrial ecosystems and their response to a changing climate $(1,2)$. Plants and soil organisms interact via a variety of different mechanisms. Plants fuel the soil food web through their belowground carbon (C) inputs, in the form of leaf and root litter, and root exudates. While soil microbes are the primary decomposers of these $C$ inputs, their biomass supports the existence of higher trophic levels, and in turn, organisms from these higher trophic levels, such as Collembola and nematodes, stimulate the activity of soil microbes. Together, the activities of these organisms release nutrients for plant growth, and determine the balance between $\mathrm{C}$ respiration and stabilisation in the soil. But these organisms also interact directly with plants in the rhizosphere, for example through feeding on, or infecting roots, through forming symbiotic relationships such as mycorrhizae, or through promoting plant growth through phytohormone production or reducing plant stress signalling. It is well known that different plant species or genotypes can select for different soil communities (3). These selective pressures are especially strong in the rhizosphere - the area around the roots that is directly influenced by root processes and that is the home of the rhizosphere microbiome. Recent studies suggest a pivotal role for root exudates in selecting the rhizosphere microbiome, and that selecting a favourable rhizosphere microbiome via altering root exudation patterns might open up new opportunities to increase plant performance, with particular benefits for crop production (4).

In many regions of the world, the frequency and duration of drought spells is predicted to increase, significantly threatening global crop yields (5). Much recent research effort is focused on harnessing rhizosphere microbial communities for making food production more sustainable (6-8), and emerging evidence shows that these microbiomes might also alleviate plant drought stress (911). However, despite an increased understanding of the mechanisms through which plants select their rhizosphere microbiomes, and the subsequent feedbacks of these microbiomes to plant growth and fitness, our understanding of these mechanisms under drought is still limited. Moreover, our understanding of the response of soil microbial communities to drought, and the implications for crop response to drought, is hampered by the fact that very little of our knowledge comes from studying how soil microbes modify plant response to drought and, of those that do, only a modest proportion focus on crop plants (Fig. S1). Here we argue that an increased understanding of the complex feedbacks between plants and microbes during, and after, drought, will pave the way for harnessing the rhizosphere microbiome to increase the resilience of crop production to drought. 
68 Drought is probably the abiotic stress that has the most dramatic effect on soil biota (12). In addition

69 to osmotic stress, drought increases soil heterogeneity, limits nutrient mobility and access, and 70 increases soil oxygen, often inducing a strong decrease in microbial biomass $(13,14)$. On short time 71 scales, the resistance of microorganisms to this drastic alteration in environmental conditions is 72 determined by specific "response traits" that protect against desiccation, like the presence of a thick 73 peptidoglycan cell wall in monoderm taxa, osmolyte production, sporulation, and dormancy (Fig. 1;

74 15-18). These traits have co-evolved convergently in diverse organisms, notably in fungi and Gram75 positive bacteria, in particular Actinomycetes (19). These organisms are described as stress-tolerant 76 strategists according to the recently proposed Y-A-S theory (high yield - resource acquisition - stress 77 tolerance; 20). This, and other frameworks, suggest a connection between drought response and 78 effect traits (generally defined as determining the effect on ecosystem functioning of the microbial 79 drought response, though here we focus on the effect of microbes on plant performance under 80 drought, Fig. 1). However, to date there is little evidence of this coupling between microbial drought tolerance mechanisms and those functional traits that affect plant performance under drought.

While much research has focused on elucidating the microbial traits responsible for drought tolerance, accumulating evidence suggests that the indirect effects via plants can outweigh the direct effects of drought on microbial communities $(21,22)$. Root exudates are an important pathway of plant-microbial communication: they provide $\mathrm{C}$ for microbial growth, but also facilitate direct communication between plants and microbes via signalling molecules and phytohormones. Drought can affect the quantity and quality of root exudates (21), and a recent study showed that the drought history of root exudates was a stronger driver of the microbial respiration induced by those root exudates than the drought history of the soil and its microbial communities (22). On longer timescales, drought-induced shifts in plant growth and abundance seem to be more important than direct effects of drought for altering soil microbial community composition, potentially through altered root exudation (4). These indirect effects of drought can induce a drastic modification of the effect traits in microbial communities that are involved in basic metabolic processes. Altered rates and composition of root exudation can trigger increased microbial mineralisation of nutrients, thus affecting plant recovery from drought (4), but longer-term changes in microbial communities have also shown to affect the fitness of subsequent plant generations under drought (9). Thus, these changes in microbial communities have the potential to affect ecosystem carbon and nitrogen cycling (22). Indeed, drought has been shown to increase the frequency of effect traits related to carbon and 
nitrogen acquisition in fungi as well as in bacteria $(23,24)$, which can feed back to plant performance under drought and during recovery after drought. On longer timescales, compositional changes in microbial communities, together with eco-evolutionary feedbacks between plants and microbes, horizontal gene transfer, and adaptation, can determine future drought responses of the plantmicrobe holobiont (25; Fig. 1, Table 1, Table 2).

Despite their hypothesised link, the correlation between microbial drought response traits, and microbial effect traits that confer an increased drought tolerance or faster recovery to plants (Fig. 1 arrow 4, Table 1), has rarely been verified. One exception is arbuscular mycorrhizal fungi (AMF, specifically Glomeromycota), which can increase in abundance under drought $(26,27$, but see 28$)$ and confer drought tolerance to their host plant by enhancing antioxidant enzyme activity, thereby reducing oxidative stress and promoting better water use efficiency and greater biomass $(8,27)$. Similarly, the enrichment of Streptomyces under drought has been evidenced to play a subsequent role in the drought-tolerance of plants $(18,29)$. Still, many of the microbial effect traits proposed as beneficial are common and shared across many microbial taxa, raising questions on their specific mode-of-action (30). Moreover, despite widespread claims of efficacy of inoculation with plant growth promoting rhizobacteria (PGPRs) under laboratory conditions, we were unable to find studies demonstrating attribution of the beneficial effect to the specific selected trait, and there is limited evidence of inoculation success and subsequent benefits for plant growth under drought in field settings. Thus, understanding the mechanisms through which soil microbes affect plant drought tolerance and recovery, and their relevance and applicability under realistic field conditions, offers much potential for making crop production systems more resilient to drought.

\section{We need a mechanistic understanding of the feedbacks between plant and microbial response to drought}

There is increasing interest in manipulating host-microbiome interactions through adding bacteria (probiotics) in a range of systems and in gut-microbe systems in particular. Guts have strong mechanistic parallels with the rhizosphere environment (31) and studies in humans provide proof of concept that manipulation of very specific feedbacks is possible with probiotics. For example, trials in babies have demonstrated microbiome invasion by a probiotic without major disruption of community structure, resulting in very specific activation of glycerol-3-phosphate (G3P) uptake genes by that community (32). Microbiome expression of G3P uptake genes has also been demonstrated as a critical response to drought in soy (17), while in sorghum it is thought to allow 
uptake and metabolisation of G3P secreted by the host plant, enabling preferential rootcolonisation by monoderm bacteria which then aide in drought tolerance (18). While probiotic manipulation may be effective (32), having identified such a specific pathway, crops, unlike human systems, are open to host engineering for adjusting that pathway (33). In addition, in humans, applying key small molecules (prebiotics) has been shown to have a host effect via the microbiome (34). For example, butyrate, a short chain fatty acid, is an important molecule for interactions within the gut microbiome, as it is, for anaerobic soil systems (35). While there is little existing evidence of efficacy such small molecule treatments in agricultural systems (36), the fundamental parallels between gut-microbiome and plant-microbiome interactions might inform targeted research into manipulating rhizosphere microbiome drought effect traits.

Plants themselves produce diverse small molecules in the rhizosphere. These primary and secondary metabolites, including volatiles, can be critical during stress $(37,38)$. For instance, in the early stages of drought, oak tree secondary metabolites play an important role in signaling to the rhizosphere; primary metabolites may serve a greater purpose during recovery (39). Interestingly, many of the drought responsive microbial metabolites described in this study act as precursors of immune phytohormones (such as phenylalanine, which is a precursor to salicylic acid (SA) biosynthesis and other stress-responsive secondary metabolites; 40), along with increased concentrations of abscisic acid (ABA). ABA plays a central role in drought tolerance in crops (41) and has long been understood to be present in the rhizosphere (42) where it is actively metabolised by rhizosphere bacteria and may be involved in helping plants tailor their rhizosphere microbial communities (43). The fact that ABA-induced sugar accumulation is the primary mechanism of drought tolerance in liverworts, ancestors to land-plants (44), also indicates that this is a highly conserved drought response pathway. Thus, engineering its activity to generate more drought resistant crops is promising (41). Furthermore, genes responsive to the immune hormones SA and jasmonic acid (JA) are downregulated in sorghum during drought (28). As SA related exudation signals are instrumental in allowing both systemic resistance and the plant-mediated development of a rhizosphere specific microbiome $(45,46)$ this is another potentially malleable pathway for influencing a drought-protective rhizosphere microbiome. However, manipulating the central plant metabolism, especially concerning immune phytohormones such as ABA, could result in undesirable outcomes, such as altered disease resistance (as is the case with ABA overexpressing mutants of Arabidopsis, which experience increased susceptibility to the biotrophic pathogen Dickeya dadantii; 47). 
167 Novel metagenomic approaches and high-resolution measurements in controlled experiments will 168 improve our understanding of the production and role of drought responsive metabolites. These 169 methods need to be employed not just during drought, where ultimately plant-microbial communication breaks down as the drought continues (3) but also after drought, when a fast sequence of physiological changes in both plant and microbes creates rapid feedback between plants and their microbiome (Fig. 3; 4). Moreover, many of these interactions may be highly context dependent. For example, investing in protective cell walls requires significant allocation of resources to build these structures, which trades-off with growth rates and competitiveness under resource-rich conditions; thus, this strategy might be selected against in agricultural soils (48). Similarly, plant cues via root exudation that stimulate microbial release of nutrients for plant regrowth after drought might either not happen or not play a role in nutrient-rich agricultural soils, where sufficient nutrients are available for plant (re)growth. Furthermore, nutrient-rich soils might increase the vulnerability of drought-stressed plants to pathogens that increase under drought (49), might select for inherently drought-sensitive plants and microbiomes $(50,51)$ and reduce the benefits and root colonisation of AMF (52). Much of our understanding of plant-microbial interactions under drought comes from non-crop species (Fig. S1), while crop species are selected for traits that might inherently compromise drought resistance and beneficial interactions with rhizosphere microbiomes $(53,54)$. Therefore, manipulating the rhizosphere microbiome via introducing the selective traits into crops, or via inoculating soils with either probiotics or prebiotics, is likely to be more successful when paralleled by other measures to increase the sustainability of agro-ecosystems (6).

\section{Putting our knowledge to work}

190 Understanding the full extent of interactions between plants and microbes, and how these are affected over time under conditions of drought, will open many new research avenues to improve plant resilience to moisture stress. Efforts should focus on crop plants, and be pursued in combination with management approaches such as minimum tillage and maintenance of plant cover, to enhance soil organic matter and soil moisture retention. To promote plant drought resistance, given the uncertainties over bio-inoculant usefulness, we emphasise here the importance of manipulating plant traits to enhance both the drought resistance of beneficial microbes, as well as promoting specific beneficial plant-microbe interactions. Such manipulations could include diversifying crops in time and space (intercropping), cultivar selection, or 
manipulation through breeding or new methodologies for localised gene editing (e.g. CRISPR; 55). More generally, calls for more advanced non-invasive phenotyping of the plant root soil system (56) need to consider microbial phenotypes and interactions with plants, and the large body of

202 knowledge on beneficial microbial traits identified in the bioinoculant literature needs to be 203 extended, incorporating ecological and evolutionary studies, to identify in-field mechanisms by which rhizosphere microbes extend the plant phenotype under periods of drought and subsequent recovery (Fig. 2).

\section{Conclusion}

Increasing our mechanistic, as well as our real-world, understanding of microbe-plant interactions under drought offers huge potential for increasing the resilience of crop production to drought. Here, we have outlined promising avenues to increase our understanding of the complex feedbacks between plant and microbial responses to drought, and argue that our research efforts will now need to focus on crop plants and be tested under realistic field conditions. Understanding the role of plant-microbe interactions during drought recovery, and in response to recurring droughts, is necessary if we are to harness these interactions not just for increasing crop resilience to drought, but also for maximising crop yields, building soil carbon and optimising soil nutrient cycling.

\section{References and notes}

1. M. G. A. Van Der Heijden, R. D. Bardgett, N. M. Van Straalen, The unseen majority: soil microbes as drivers of plant diversity and productivity in terrestrial ecosystems. Ecol. Lett. 11, 296-310 (2008).

2. R. Cavicchioli, W. J. Ripple, K. N. Timmis, F. Azam, L. R. Bakken, M. Baylis, M. J. Behrenfeld, A. Boetius, P. W. Boyd, A. T. Classen, T. W. Crowther, R. Danovaro, C. M. Foreman, J. Huisman, D. A. Hutchins, J. K. Jansson, D. M. Karl, B. Koskella, D. B. Mark Welch, J. B. H. Martiny, M. A. Moran, V. J. Orphan, D. S. Reay, J. V. Remais, V. I. Rich, B. K. Singh, L. Y. Stein, F. J. Stewart, M. B. Sullivan, M. J. H. van Oppen, S. C. Weaver, E. A. Webb, N. S. Webster, Scientists' warning to humanity: microorganisms and climate change. Nat. Rev. Microbiol. 17, 569-586 (2019).

3. R. L. Berendsen, C. M. J. Pieterse, P. A. H. M. Bakker, The rhizosphere microbiome and plant health. Trends Plant Sci. 17, 478-486 (2012).

4. A. Williams, F. T. de Vries, Plant root exudation under drought: implications for ecosystem functioning. New Phytol. 225, 1899-1905 (2020).

5. Intergovernmental Panel on Climate Change (IPCC), V Masson-Delmotte, P Zhai, HO Pörtner, D Roberts, J Skea, PR Shukla, A Pirani, W Moufouma-Okia, C Péan, R Pidcock, S Connors, JBR Matthews, Y Chen, X Zhou, MI Gomis, E Lonnoy, T Maycock, M Tignor, T 
Waterfield, eds., in Global warming of $1.5^{\circ} \mathrm{C}$ (Cambridge, UK: Cambridge University Press., 2018).

6. S. F. Bender, C. Wagg, M. G. A. van der Heijden, An underground revolution: biodiversity and soil ecological engineering for agricultural sustainability. Trends Ecol. Evol. 31, 440452 (2016).

7. F. T. de Vries, M. D. Wallenstein, Below-ground connections underlying above-ground food production: a framework for optimising ecological connections in the rhizosphere. J. Ecol. 105, 913-920 (2017).

8. T. J. Thirkell, M. D. Charters, A. J. Elliott, S. M. Sait, K. J. Field, Are mycorrhizal fungi our sustainable saviours? Considerations for achieving food security. J. Ecol. 105, 921-929 (2017).

9. J. A. Lau, J. T. Lennon, Rapid responses of soil microorganisms improve plant fitness in novel environments. Proc. Natl. Acad. Sci. 109, 14058-14062 (2012).

10. X. Niu, L. Song, Y. Xiao, W. Ge, Drought-tolerant plant growth-promoting rhizobacteria associated with foxtail millet in a semi-arid agroecosystem and their potential in alleviating drought stress. Front. Microbiol. 8 (2018).

11. R. L. Rubin, K. J. van Groenigen, B. A. Hungate, Plant growth promoting rhizobacteria are more effective under drought: a meta-analysis. Plant Soil. 416, 309-323 (2017).

12. G. Leng, J. Hall, Crop yield sensitivity of global major agricultural countries to droughts and the projected changes in the future. Sci. Total Environ. 654, 811-821 (2019).

13. D. Naylor, D. Coleman-Derr, Drought stress and root-associated bacterial communities. Front. Plant Sci. 8, 2223 (2018).

14. J. K. Jansson, K. S. Hofmockel, Soil microbiomes and climate change. Nat. Rev. Microbiol. (2019).

15. J. Schimel, T. C. Balser, M. Wallenstein, Microbial stress-response physiology and its implications for ecosystem function. Ecology. 88, 1386-1394 (2007).

16. A. C. Martiny, K. Treseder, G. Pusch, Phylogenetic conservatism of functional traits in microorganisms. ISME J. 7, 830-838 (2013).

17. L. Xu, D. Naylor, Z. Dong, T. Simmons, G. Pierroz, K. K. Hixson, Y.-M. Kim, E. M. Zink, K. M. Engbrecht, Y. Wang, C. Gao, S. DeGraaf, M. A. Madera, J. A. Sievert, J. Hollingsworth, D. Birdseye, H. V. Scheller, R. Hutmacher, J. Dahlberg, C. Jansson, J. W. Taylor, P. G. Lemaux, D. Coleman-Derr, Drought delays development of the sorghum root microbiome and enriches for monoderm bacteria. Proc. Natl. Acad. Sci. 115, E4284-E4293 (2018).

18. L. Xu, D. Coleman-Derr, Causes and consequences of a conserved bacterial root microbiome response to drought stress. Environ. Microbiol. 49, 1-6 (2019). 
19. J. B. Martiny, A. C. Martiny, C. Weihe, Y. Lu, R. Berlemont, E. L. Brodie, M. L. Goulden, K. K. Treseder, S. D. Allison, Microbial legacies alter decomposition in response to simulated global change. ISME J. 11, 490-499 (2017).

20. A. A. Malik, J. B. H. Martiny, E. L. Brodie, A. C. Martiny, K. K. Treseder, S. D. Allison, Defining trait-based microbial strategies with consequences for soil carbon cycling under climate change. ISME J., 1-9 (2020).

21. C. Preece, J. Peñuelas, Rhizodeposition under drought and consequences for soil communities and ecosystem resilience. Plant Soil. 409, 1-17 (2016).

22. F. T. de Vries, A. Williams, F. Stringer, R. Willcocks, R. McEwing, H. Langridge, A. L. Straathof, Changes in root-exudate-induced respiration reveal a novel mechanism through which drought affects ecosystem carbon cycling. New Phytol. 224, 132-145 (2019).

23. N. J. Bouskill, T. E. Wood, R. Baran, Z. Hao, Z. Ye, B. P. Bowen, H. C. Lim, P. S. Nico, H.Y. Holman, B. Gilbert, W. L. Silver, T. R. Northen, E. L. Brodie, Belowground response to drought in a tropical forest soil. II. Change in microbial function impacts carbon composition. Front. Microbiol. 7, 323 (2016).

24. K. K. Treseder, R. Berlemont, S. D. Allison, A. C. Martiny, Drought increases the frequencies of fungal functional genes related to carbon and nitrogen acquisition. PLOS ONE. 13 (2018).

25. C. V. Hawkes, B. G. Waring, J. D. Rocca, S. N. Kivlin, Historical climate controls soil respiration responses to current soil moisture. Proc. Natl. Acad. Sci. 114, 6322-6327 (2017).

26. F. T. de Vries, R. I. Griffiths, M. Bailey, H. Craig, M. Girlanda, H. S. Gweon, S. Hallin, A. Kaisermann, A. M. Keith, M. Kretzschmar, P. Lemanceau, E. Lumini, K. E. Mason, A. Oliver, N. Ostle, J. I. Prosser, C. Thion, B. Thomson, R. D. Bardgett, Soil bacterial networks are less stable under drought than fungal networks. Nat. Commun. 9, 3033 (2018).

27. J. Li, B. Meng, H. Chai, X. Yang, W. Song, S. Li, A. Lu, T. Zhang, W. Sun, Arbuscular mycorrhizal fungi alleviate drought stress in C3 (Leymus chinensis) and C4 (Hemarthria altissima) grasses via altering antioxidant enzyme activities and photosynthesis. Front. Plant Sci. 10, 499 (2019).

28. N. Varoquaux, B. Cole, C. Gao, G. Pierroz, C. R. Baker, D. Patel, M. Madera, T. Jeffers, J. Hollingsworth, J. Sievert, Y. Yoshinaga, J. A. Owiti, V. R. Singan, S. DeGraaf, L. Xu, M. J. Blow, M. J. Harrison, A. Visel, C. Jansson, K. K. Niyogi, R. Hutmacher, D. Coleman-Derr, R. C. O'Malley, J. W. Taylor, J. Dahlberg, J. P. Vogel, P. G. Lemaux, E. Purdom, Transcriptomic analysis of field-droughted sorghum from seedling to maturity reveals biotic and metabolic responses. Proc. Natl. Acad. Sci. 116, 27124 (2019).

29. C. R. Fitzpatrick, J. Copeland, P. W. Wang, D. S. Guttman, P. M. Kotanen, M. T. J. Johnson, Assembly and ecological function of the root microbiome across angiosperm plant species. Proc. Natl. Acad. Sci. 115, E1157-E1165 (2018). 
30. O. M. Finkel, G. Castrillo, S. Herrera Paredes, I. Salas González, J. L. Dangl, Understanding and exploiting plant beneficial microbes. Curr. Opin. Plant Biol. 38, 155163 (2017).

31. S. T. Ramirez-Puebla, L. E. Servin-Garciduenas, B. Jimenez-Marin, L. M. Bolanos, M. Rosenblueth, J. Martinez, M. A. Rogel, E. Ormeno-Orrillo, E. Martinez-Romero, Gut and root microbiota commonalities. Appl Env. Microbiol. 79, 2-9 (2013).

32. Murphy R, Morgan XC, Wang XY, Wickens K, Purdie G, Fitzharris P, Otal A, Lawley B, Stanley T, Barthow C, Crane J., Eczema-protective probiotic alters infant gut microbiome functional capacity but not composition: sub-sample analysis from a RCT. Benef. Microbes. 10, 5-17 (2019).

33. M. Foo, I. Gherman, P. Zhang, D. G. Bates, K. J. Denby, A framework for engineering stress resilient plants using genetic feedback control and regulatory network rewiring. ACS Synth. Biol. 7, 1553-1564 (2018).

34. É. Szentirmai, N. S. Millican, A. R. Massie, L. Kapás, Butyrate, a metabolite of intestinal bacteria, enhances sleep. Sci. Rep. 9, 1-9 (2019).

35. P. Liu, Q. Qiu, Y. Lu, Syntrophomonadaceae-affiliated species as active butyrate-utilizing syntrophs in paddy field soil. Appl. Environ. Microbiol. 77, 3884-3887 (2011).

36. E. B. G. Feibert, C. C. Shock, L. D. Saunders, Nonconventional additives leave onion yield and quality unchanged. HortScience HortSci. 38, 381-386 (2003).

37. M. A. Farag, H. Zhang, C.-M. Ryu, Dynamic chemical communication between plants and bacteria through airborne signals: induced resistance by bacterial volatiles. J. Chem. Ecol. 39, 1007-1018 (2013).

38. Ahmad P, Ahanger MA, Singh VP, Tripathi DK, Alam P, Alyemeni MN, Plant metabolites and regulation under environmental stress. (Academic Press, 1st edition., 2018).

39. A. Gargallo-Garriga, C. Preece, J. Sardans, M. Oravec, O. Urban, J. Peñuelas, Root exudate metabolomes change under drought and show limited capacity for recovery. Sci. Rep. 8, 1-15 (2018).

40. T. Tohge, M. Watanabe, R. Hoefgen, A. Fernie, Shikimate and phenylalanine biosynthesis in the green lineage. Front. Plant Sci. 4, 62 (2013).

41. S. K. Sah, K. R. Reddy, J. Li, Abscisic acid and abiotic stress tolerance in crop plants. Front. Plant Sci. 7, 571 (2016).

42. W. Hartung, A. Sauter, N. C. Turner, I. Fillery, H. Heilmeier, Abscisic acid in soils: What is its function and which factors and mechanisms influence its concentration? Plant Soil. 184, 105-110 (1996).

43. A. A. Belimov, I. C. Dodd, V. I. Safronova, V. A. Dumova, A. I. Shaposhnikov, A. G. Ladatko, W. J. Davies, Abscisic acid metabolizing rhizobacteria decrease ABA concentrations in planta and alter plant growth. Plant Physiol. Biochem. 74, 84-91 (2014). 
44. A. Jahan, K. Komatsu, M. Wakida-Sekiya, M. Hiraide, K. Tanaka, R. Ohtake, T. Umezawa, T. Toriyama, A. Shinozawa, I. Yotsui, Y. Sakata, D. Takezawa, Archetypal roles of an abscisic acid receptor in drought and sugar responses in liverworts. Plant Physiol. 179, 317-328 (2019).

45. S. L. Lebeis, S. H. Paredes, D. S. Lundberg, N. Breakfield, J. Gehring, M. McDonald, S. Malfatti, T. Glavina del Rio, C. D. Jones, S. G. Tringe, J. L. Dangl, Salicylic acid modulates colonization of the root microbiome by specific bacterial taxa. Science. 349, 860-864 (2015).

46. Bakker PA, Doornbos RF, Zamioudis C, Berendsen RL, Pieterse CM, Induced systemic resistance and the rhizosphere microbiome. Plant Pathol. J. 29, 136 (2013).

47. F. Van Gijsegem, J. Pédron, O. Patrit, E. Simond-Côte, A. Maia-Grondard, P. Pétriacq, R. Gonzalez, L. Blottière, Y. Kraepiel, Manipulation of ABA content in Arabidopsis thaliana modifies sensitivity and oxidative stress response to Dickeya dadantii and influences peroxidase activity. Front. Plant Sci. 8, 456 (2017).

48. M. D. Wallenstein, E. K. Hall, A trait-based framework for predicting when and where microbial adaptation to climate change will affect ecosystem functioning. Biogeochemistry. 109, 35-47 (2012).

49. A. Meisner, W. de Boer, Strategies to maintain natural biocontrol of soil-borne crop diseases during severe drought and rainfall events. Front. Microbiol. 9, 2279 (2018).

50. U. Friedrich, G. von Oheimb, W.-U. Kriebitzsch, K. Schleßelmann, M. S. Weber, W. Härdtle, Nitrogen deposition increases susceptibility to drought - experimental evidence with the perennial grass Molinia caerulea (L.) Moench. Plant Soil. 353, 59-71 (2012).

51. F. T. de Vries, M. E. Liiri, L. Bjørnlund, M. A. Bowker, S. Christensen, H. M. Setälä, R. D. Bardgett, Land use alters the resistance and resilience of soil food webs to drought. Nat. Clim. Change. 2, 276-280 (2012).

52. N. C. Johnson, Can fertilization of soil select less mutualistic mycorrhizae? Ecol. Appl. 3, 749-757 (1993).

53. S. Matesanz, R. Milla, Differential plasticity to water and nutrients between crops and their wild progenitors. Environ. Exp. Bot. 145, 54-63 (2018).

54. Z. Wen, H. Li, Q. Shen, X. Tang, C. Xiong, H. Li, J. Pang, M. H. Ryan, H. Lambers, J. Shen, Tradeoffs among root morphology, exudation and mycorrhizal symbioses for phosphorus-acquisition strategies of 16 crop species. New Phytol. 223, 882-895 (2019).

55. Z. Qiu, E. Egidi, H. Liu, S. Kaur, B. K. Singh, New frontiers in agriculture productivity: Optimised microbial inoculants and in situ microbiome engineering. Biotechnol. Adv. (2019).

56. S. R. Tracy, K. A. Nagel, J. A. Postma, H. Fassbender, A. Wasson, M. Watt, Crop improvement from phenotyping roots: highlights reveal expanding opportunities. Trends Plant Sci. (2019). 
57. C. S. Francisco, X. Ma, M. M. Zwyssig, B. A. McDonald, J. Palma-Guerrero, Morphological changes in response to environmental stresses in the fungal plant pathogen Zymoseptoria tritici. Sci. Rep. 9, 1-18 (2019).

58. D. Naylor, S. DeGraaf, E. Purdom, D. Coleman-Derr, Drought and host selection influence bacterial community dynamics in the grass root microbiome | The ISME Journal (2017), (available at https://www.nature.com/articles/ismej2017118\#citeas).

59. N. Khan, A. Bano, Exopolysaccharide producing rhizobacteria and their impact on growth and drought tolerance of wheat grown under rainfed conditions. PLOS ONE. 14, e0222302 (2019).

60. S. S. K. P. Vurukonda, S. Vardharajula, M. Shrivastava, A. SkZ, Enhancement of drought stress tolerance in crops by plant growth promoting rhizobacteria. Microbiol. Res. 184, 1324 (2016).

61. M. D. Jochum, K. L. McWilliams, E. J. Borrego, M. V. Kolomiets, G. Niu, E. A. Pierson, Y.K. Jo, Bioprospecting Plant Growth-Promoting Rhizobacteria That Mitigate Drought Stress in Grasses. Front. Microbiol. 10 (2019), doi:10.3389/fmicb.2019.02106.

62. J. Chiappero, L. del R. Cappellari, L. G. Sosa Alderete, T. B. Palermo, E. Banchio, Plant growth promoting rhizobacteria improve the antioxidant status in Mentha piperita grown under drought stress leading to an enhancement of plant growth and total phenolic content. Ind. Crops Prod. 139, 111553 (2019).

63. S. Vurukonda, S. Vardharajula, M. Shrivastava, A. Skz, Enhancement of drought stress tolerance in crops by plant growth promoting rhizobacteria. Microbiol. Res. 184 (2015).

64. M. Moshelion, O. Halperin, R. Wallach, R. Oren, D. A. Way, Role of aquaporins in determining transpiration and photosynthesis in water-stressed plants: crop water-use efficiency, growth and yield. Plant Cell Environ. 38, 1785-1793 (2015).

65. L. Szabados, A. Savouré, Proline: a multifunctional amino acid. Trends Plant Sci. 15, 8997 (2010).

66. T. D. Eldhuset, N. E. Nagy, D. Volařík, I. Børja, R. Gebauer, I. A. Yakovlev, P. Krokene, Drought affects tracheid structure, dehydrin expression, and above- and belowground growth in 5-year-old Norway spruce. Plant Soil. 366, 305-320 (2013).

67. J. Lipiec, C. Doussan, A. Nosalewicz, K. Kondracka, Effect of drought and heat stresses on plant growth and yield: a review. Int. Agrophysics Lub. 27, 463-477 (2013).

68. M. A. Ahmed, E. Kroener, M. Holz, M. Zarebanadkouki, A. Carminati, Mucilage exudation facilitates root water uptake in dry soils. Funct. Plant Biol. 41, 1129-1137 (2014).

69. M. K. van der Molen, A. J. Dolman, P. Ciais, T. Eglin, N. Gobron, B. E. Law, P. Meir, W. Peters, O. L. Phillips, M. Reichstein, T. Chen, S. C. Dekker, M. Doubková, M. A. Friedl, M. Jung, B. J. J. M. van den Hurk, R. A. M. de Jeu, B. Kruijt, T. Ohta, K. T. Rebel, S. Plummer, S. I. Seneviratne, S. Sitch, A. J. Teuling, G. R. van der Werf, G. Wang, Drought and ecosystem carbon cycling. Agric. For. Meteorol. 151, 765-773 (2011). 


\section{$424 \quad$ Funding}

425 This work was funded by a NERC Discovery Grant (NE/P01206X/1) and a BBSRC David Phillips 426 Fellowship to FTdV (BB/L02456X/1).

427

\section{Author contributions}

429 All authors conceived the idea for the manuscript. FTdV led the writing of the manuscript, with 430 inputs from all authors.

\section{Competing interests}

433 There are no competing interests

434

435 Data and materials availability

436 All data is available in the supplementary materials

437

438 Supplementary Materials

439 Figure S1

440 Data S1

441

442 


\section{Table 1 Microbial community response and effect traits during drought}

\begin{tabular}{|c|c|c|c|c|}
\hline $\begin{array}{l}\text { Response or } \\
\text { effect }\end{array}$ & Trait & Description & $\begin{array}{l}\text { Has this been } \\
\text { observed in } \\
\text { the field? }\end{array}$ & References \\
\hline Response & $\begin{array}{l}\text { Cell wall } \\
\text { architecture }\end{array}$ & $\begin{array}{l}\text { Monoderm (gram positive) increase relative to } \\
\text { diderms - thicker cell walls mean increased resistance } \\
\text { to water stress. }\end{array}$ & Field & $\begin{array}{l}\text { Xu et al. } 2018 \\
(17)\end{array}$ \\
\hline Response & $\begin{array}{l}\text { Morphology, } \\
\text { filamentous } \\
\text { hyphae }\end{array}$ & $\begin{array}{l}\text { In certain fungi access to spatially separated sources } \\
\text { of water during drought through production of } \\
\text { filamentous structures. This may aide host or increase } \\
\text { pathogenic fungi. }\end{array}$ & Field & $\begin{array}{l}\text { Francisco et } \\
\text { al. } 2019(57)\end{array}$ \\
\hline Response & Sporulation & $\begin{array}{l}\text { Protective spore production can promote persistence } \\
\text { in the soil in certain species during extreme drought. } \\
\text { Drought itself reduces the ability to sporulate. }\end{array}$ & $\begin{array}{c}\text { Field, } \\
\text { observational. }\end{array}$ & $\begin{array}{l}\text { Naylor et al. } \\
2017(58)\end{array}$ \\
\hline $\begin{array}{l}\text { Response and } \\
\text { effect }\end{array}$ & EPS/ Biofilm & $\begin{array}{l}\text { Production of an EPS matrix in mixed microbial } \\
\text { communities generates an environment that is more } \\
\text { osmotically stable during drought }\end{array}$ & CE & $\begin{array}{l}\text { Khan \& Bano } \\
2019(59)\end{array}$ \\
\hline $\begin{array}{l}\text { Response and } \\
\text { effect }\end{array}$ & $\begin{array}{l}\text { Osmoprotecti } \\
\text { on }\end{array}$ & $\begin{array}{l}\text { Production of osmolytes by microbes and stimulation } \\
\text { of osmolyte production in the roots via microbially } \\
\text { derived signals impart a more stable osmotic } \\
\text { environment during drought stress }\end{array}$ & CE & $\begin{array}{l}\text { Vurukonda } \\
\text { et al. } \quad 2016 \\
(60)\end{array}$ \\
\hline Effect & $\begin{array}{l}\text { Root } \\
\text { elongation via } \\
\text { IAA }\end{array}$ & $\begin{array}{l}\text { Bacteria produce auxins (IAA) and gibberellins during } \\
\text { drought which act as growth stimulators, altering root } \\
\text { morphology for greater water acquisition }\end{array}$ & CE & $\begin{array}{l}\text { Jochum et al. } \\
2019(61)\end{array}$ \\
\hline Effect & $\begin{array}{l}\text { antimicrobial } \\
\text { / allelopathy }\end{array}$ & $\begin{array}{l}\text { Certain PGPM promote their own survival and } \\
\text { potentially limit the growth of pathogens by producing } \\
\text { allelopathic and antimicrobial molecules }\end{array}$ & $\begin{array}{c}\text { Field, } \\
\text { observational }\end{array}$ & $\begin{array}{l}\text { Bouskill et al. } \\
2016(23)\end{array}$ \\
\hline Effect & $\begin{array}{l}\text { Antioxidant } \\
\text { production }\end{array}$ & $\begin{array}{l}\text { Drought leads to oxidative stress and internal cell } \\
\text { damage. This can be directly mitigated by certain }\end{array}$ & $\begin{array}{c}\text { Field, } \\
\text { observational }\end{array}$ & $\begin{array}{l}\text { Chiaperro et } \\
\text { al. } 2019(62)\end{array}$ \\
\hline
\end{tabular}


Effect $\mathrm{ABA}$
augmentation

Effect
Direct production, and stimulation, of the phytohormone ABA allows a greater drought stress response through holistic reorchestration of water use (Table S2). uisition via enzymes

Nutrient
acquisition via
enzymes

Greater $\mathrm{C}$ and $\mathrm{N}$ scavenging enzyme production during drought can provide access to limited resources which are less available during drought
CE

Vurukonda et al. 2016 (63)

Field

Bouskill et al. 2016 (23)

EPS exopolysaccharide matrix; IAA indole acetic acid; ABA abscisic acid; PGPR plant growth promoting microorganisms; ROS reactive oxygen species; CE controlled environment 


\begin{tabular}{|c|c|c|c|c|}
\hline $\begin{array}{l}\text { Response } \\
\text { or Effect }\end{array}$ & Trait & Description & $\begin{array}{l}\text { Has this been } \\
\text { observed in } \\
\text { the field? }\end{array}$ & References \\
\hline Response & $\begin{array}{c}\text { Transpiration } \\
\text { and water use } \\
\text { decreased }\end{array}$ & $\begin{array}{l}\text { Through changes in hormonal signalling, inducing } \\
\text { stomatal closure, water loss is decreased. Increased } \\
\text { cuticular wax deposition aides in foliar water } \\
\text { retention. }\end{array}$ & Field & $\begin{array}{l}\text { Moshelion et } \\
\text { al. } 2014(64)\end{array}$ \\
\hline Response & $\begin{array}{l}\text { Osmoprotectiv } \\
\text { e physiology } \\
\text { favoured }\end{array}$ & $\begin{array}{l}\text { Induced changes in antioxidant physiology to protect } \\
\text { plants from oxidative stress }\end{array}$ & Field & $\begin{array}{l}\text { Szabados \& } \\
\text { Savouré, } \\
2010(65)\end{array}$ \\
\hline Response & $\begin{array}{l}\text { Root hydraulic } \\
\text { conductance } \\
\text { increases }\end{array}$ & $\begin{array}{l}\text { Aquaporin expression increases during drought. } \\
\text { Dehydrin production promotes an osmotically stable } \\
\text { environment. }\end{array}$ & Field & $\begin{array}{l}\text { Eldhuset } e t \\
\text { al. } 2013(66)\end{array}$ \\
\hline Response & $\begin{array}{l}\text { Development } \\
\text { limited }\end{array}$ & $\begin{array}{l}\text { Photosynthetic activity decreases, foliar growth stops, } \\
\text { root shoot ratio increases. }\end{array}$ & Field & $\begin{array}{l}\text { Lipiec et al. } \\
2013(67)\end{array}$ \\
\hline Effect & $\begin{array}{l}\text { Changes in root } \\
\text { exudation } \\
\text { chemistry }\end{array}$ & $\begin{array}{l}\text { This occurs as both quantity and composition of root } \\
\text { exudates are responsive to drought. Different } \\
\text { compositions are likely to influence a root } \\
\text { microbiome that is more conducive to drought } \\
\text { tolerance }\end{array}$ & CE & $\begin{array}{l}\text { De Vries et al. } \\
2019(22) ; \\
\text { Williams and } \\
\text { de Vries } \\
2020(4)\end{array}$ \\
\hline Effect & $\begin{array}{l}\text { Increased } \\
\text { mucilage } \\
\text { production }\end{array}$ & $\begin{array}{l}\text { More mucilage excretion around the roots helps to } \\
\text { create a more osmotically positive environment. }\end{array}$ & CE & $\begin{array}{l}\text { Ahmed et al. } \\
2014(68)\end{array}$ \\
\hline Effect & $\begin{array}{l}\text { Altered soil C } \\
\quad \text { flux }\end{array}$ & $\begin{array}{l}\text { Changes in soil } \mathrm{C} \text { deposition, as well as its degradation } \\
\text { and feedback into the atmosphere during drought. }\end{array}$ & CE & $\begin{array}{l}\text { van der } \\
\text { Molen et al. } \\
2011(69)\end{array}$ \\
\hline
\end{tabular}

CE - controlled environment 


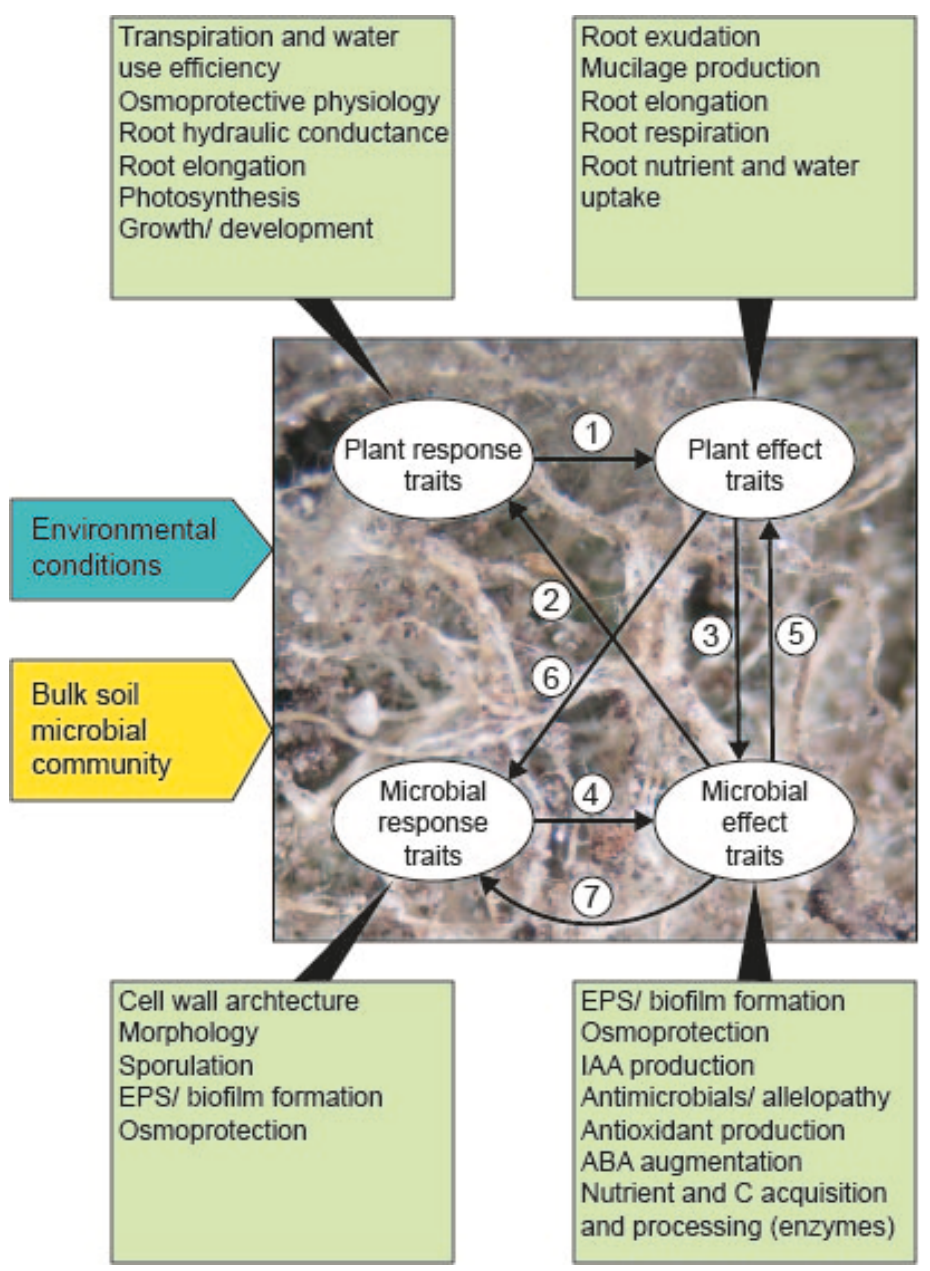

Figure 1. Relationships between plant drought response and effect traits, and microbial drought response and effect traits. Drought response traits determine the direct response of plants and microbes to drought, and these traits have a hypothesised link with drought effect traits (arrows 1 and 4), which determine the effect of drought on the plant. Plant and microbial effects traits can feedback to each other (arrows 3 and 5) and determine plant and microbial response to drought (arrows 2 and 6). Microbial effect traits can also feed back to influence microbial response to drought (arrow 7). All traits are affected by environmental conditions and bulk soil microbial communities. Morphology refers to filamentous hyphal growth of fungi. EPS is exopolysaccharide, ABA is abscisic acid, IAA is indole acetic acid. References for the traits included here can be found in Tables 1 and 2. 

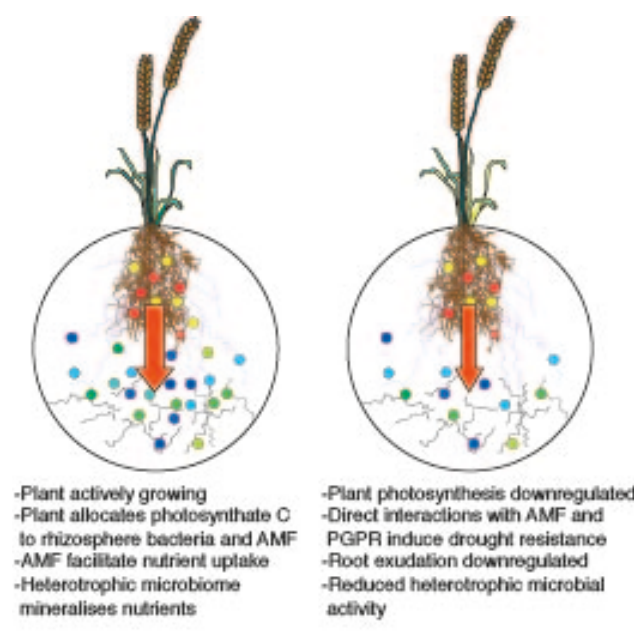

Helerotrophic microbiome activity

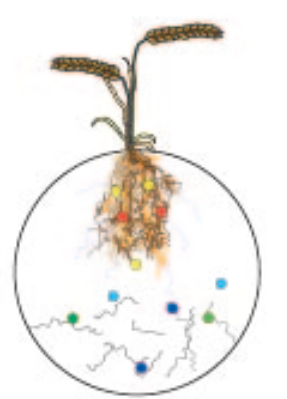

halled

Plant and microbial cell death

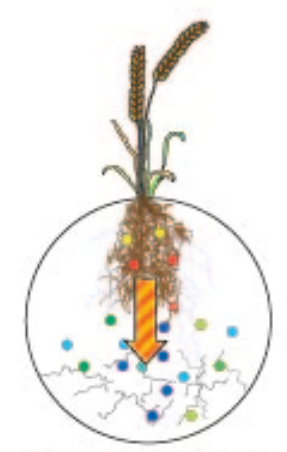

-Plant photosynthesis/growent

-Altered root exudation triggees

heterotrophic microbid activity

-Increased mineralieation of C

and nutrients

-Stimulated plant growth alters

soil emvironment:

-Irleractions between roots and

microbes permanently atered

Figure 2. Hypothesised alterations in plant-microbial interactions during and after drought.

471 During drought, direct interactions with PGPR and AMF induce plant drought tolerance, but these

472 interactions break down under severe or continuing drought. After drought, different plant-

473 microbial interactions are assembled, with the potential of affecting future plant and soil response 474 to drought. 


\section{Science AlAAAS}

\section{Supplementary Materials for}

\section{Harnessing rhizosphere microbiomes for drought resilient crop production}

Franciska T. de Vries ${ }^{1,2 *}$, Rob I. Griffiths ${ }^{3}$, Christopher G. Knight ${ }^{1}$, Oceane Nicolitch ${ }^{1}$, Alex Williams ${ }^{1}$

1 Department of Earth and Environmental Sciences, The University of Manchester, Oxford

Road, M13 9PT, Manchester, UK

2 Institute for Biodiversity and Ecosystem Dynamics, University of Amsterdam, PO

Box 94240, 1090 GE Amsterdam, The Netherlands.

${ }^{3}$ CEH Bangor, Environment Centre Wales, Deiniol Rd, Bangor, LL57 2UW

*Corresponding author - f.t.devries@uva.nl

This PDF file includes:

Fig. S1

Caption for Data S1

Other Supplementary Materials for this manuscript include the following:

Data S1 
Fig. S1.
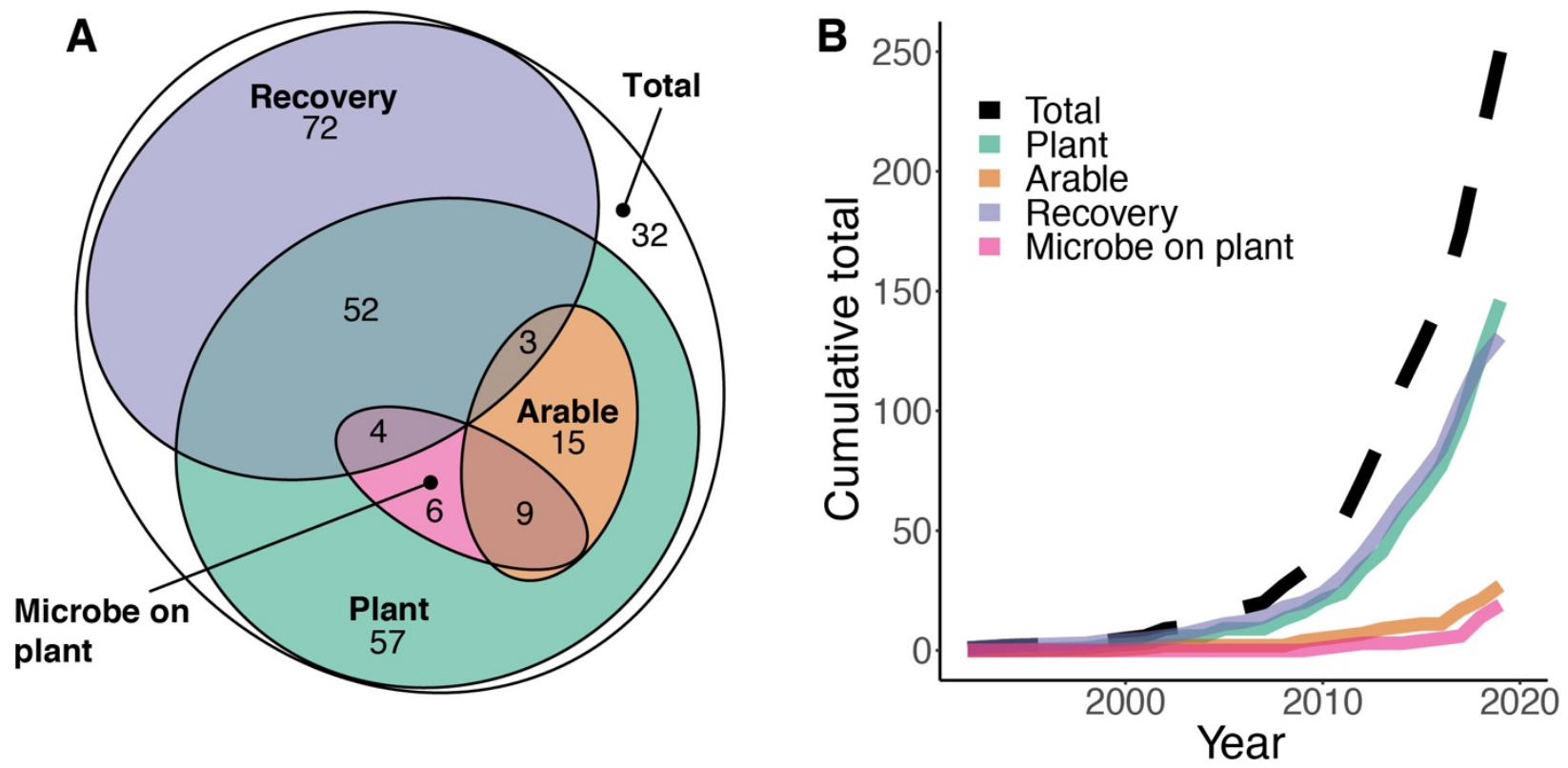

Figure S1. Effects of drought on soil microbial communities: the literature. Two hundred and fifty papers dealing with drought and soil microbial communities ('Total') were classified by whether they involved plants ('Plant'), whether they included recovery from drought ('Recovery'), whether they used an arable plant or crop ('Arable'), and whether they specifically considered the effect of soil microbes on plant drought response ('Microbe on plant'). A Euler diagram of all papers, showing that no papers tested the effect of microbes on an arable plant through recovery from drought. $\mathbf{B}$ The recent large growth in relevant papers has largely ignored arable systems and microbes on plants. Papers were identified using Web of Science and at least one of the following four search terms: drought effects soil (fungal OR bacterial) microbial; drought effects soil "microbial community"; (drying OR drying-rewetting OR dry-wet) effects soil (fungal OR bacterial) microbial; (drying or drying-rewetting OR dry-wet) effects soil "microbial community". Full list of papers is available as Data S1. 
Data S1. (separate file)

File containing al papers used for Fig. S1, as extracted from Web of Science with the search terms specified in Fig. S1. 